\title{
Saccharomyces cerevisiae whi2 Mutants in Stationary Phase Retain the Properties of Exponentially Growing Cells
}

\author{
By D. J. SAUL,${ }^{1} \dagger$ E. F. WALTON ${ }^{2} \ddagger$ P. E. SUDBERY ${ }^{1 *}$ AND \\ B. L. A. CARTER ${ }^{2} \S$ \\ ${ }^{1}$ Department of Genetics, University of Sheffield, Sheffield S10 2TN, UK \\ ${ }^{2}$ Department of Genetics, Trinity College, Lincoln Place Gate, Dublin 2, Eire
}

(Received II January 1985 ; revised 8 May 1985)

\begin{abstract}
Stationary phase cultures of whi2 mutants of Saccharomyces cerevisiae were tested to discover whether they had undergone the changes which wild-type cells show in response to nutrient deprivation. The sensitivity to a $52{ }^{\circ} \mathrm{C}$ heat shock, nystatin treatment and Zymolyase digestion of the cell wall was determined in isogenic $\mathrm{WHI}^{+}$and whi2 strains in both exponential and stationary growth phases. In each case, $\mathrm{WHI}^{+}$cells become more resistant to these treatments in stationary phase but whi2 cells in stationary phase retained the sensitivity of exponential cultures. In addition, glycogen accumulation was reduced in the whi2 mutant, and DAPI fluorescent staining of the nuclei revealed that nuclear cycle arrest did not occur in G1, but at a minimum of three different phases of the cell cycle. We conclude that under the conditions of deprivation which occur in stationary phase, whi 2 mutants retain the properties of exponentially growing cells.
\end{abstract}

\section{INTRODUCTION}

whi 2 is a mutation of Saccharomyces cerevisiae which disturbs the normal coordination of cell proliferation with nutrient availability (Sudbery et al., 1980). Batch cultures of wild-type cells grown on complex YEPD medium cease proliferating when the carbon source becomes limiting in stationary phase, cell cycle arrest occurs in Gl and cells accumulate in the unbudded state (Hartwell, 1974). In contrast, whi2 cells continue dividing as the carbon supply becomes exhausted, the consequent division without cell growth results in cells becoming smaller and a higher cell density (number of cells per ml of culture) is eventually attained. The cells arrest in the budded state, apparently randomly distributed in the cell cycle (Sudbery et al., 1980).

As wild-type cells enter stationary phase a series of concerted changes occur in cell physiology, giving rise to a number of differences in the properties of stationary phase cells compared to exponentionally growing cells. Thus stationary phase cells are more resistant to a $52{ }^{\circ} \mathrm{C}$ heat shock (Parry et al., 1976; Schenberg-Frascino \& Moustacchi, 1971; Walton et al., 1979), to nystatin treatment (Snow, 1966; Thouvenot \& Bourgeois, 1971) and to spheroplast formation (Deutch \& Parry, 1973). They appear phase bright under phase contrast optics compared to the phase dark appearance of exponentially growing cells, and contain a higher proportion of glycogen and trehalose accumulated in the last few rounds of division before arrest (Lillie \& Pringle, 1980). The quiescent cells contain a single unreplicated nucleus.

In this paper we investigate the properties of whi2 cells as the carbon supply is limited in batch culture growth and the cells enter stationary phase. We show that the cells fail to show the

\footnotetext{
$\dagger$ Present address: Department of Cell Biology, University of Auckland, New Zealand.

¥ Present address: Microbial Genetics Department, Celltech Ltd, 244-250 Bath Rd, Slough SL1 4DY, UK.

$\S$ Present address: Searle Research and Development, Division of G. D. Searle Ltd, Lane End Rd, High Wycombe, Bucks, UK.
} 
changes which normally occur as cells enter stationary phase, and we confirm that there is no single point in the cell cycle where arrest preferentially occurs.

\section{METHODS}

Strains. X4003-5B (a adel his 4 met 2 ura 3 trp 5 and X2180 1A (wild-type) were from the Yeast Stock Center, Berkeley, Calif., USA). M11-30 is a $\mathrm{Met}^{-}$derivative of M11 ( $\alpha$ whi2) recovered after EMS mutagenesis.

Media and culture conditions. Complex YEPD medium, presporulation and sporulation media were all as described by Sherman et al. (1974). Stock cultures of yeasts strains were grown overnight in liquid YEPD medium at $28{ }^{\circ} \mathrm{C}$ on a rotary shaker, and $0.1 \mathrm{ml}$ was re-inoculated into fresh medium, keeping the volume of the culture below one-tenth of the flask volume to ensure good aeration. Exponential phase cultures were permitted to grow to $\mathrm{OD}_{600} 0 \cdot 6$. Stationary phase cultures were grown for $48 \mathrm{~h}$.

Heat treatment of culture. Cultures were exposed to elevated temperatures in a shaking water bath at $52{ }^{\circ} \mathrm{C}$. A sample was taken at 'zero' time, and appropriate dilutions were plated onto YEPD agar medium to determine the number of viable cells which were present initially. At intervals during the incubation period $0.1 \mathrm{ml}$ samples were removed, diluted and plated onto YEPD agar plates. Colonies were counted after $3 \mathrm{~d}$ growth at $28^{\circ} \mathrm{C}$. Three dilutions were plated aiming at an optimum of 50-500 colonies per plate and all experiments were done three times (Schenberg-Frascino \& Moustacchi, 1974).

Nystatin treatment of cultures. Cells were grown to exponential phase and stationary phase as above and the $\mathrm{pH}$ of the culture adjusted to $4 \cdot 2$ to maximize the antibiotic effect as described by Snow (1966). Preliminary experiments were done to determine the concentration of nystatin (Mycostatin, Squibb) required for a measurable kill rate (100 $\mathrm{U} \mathrm{ml}^{-1}$ gave optimum results). As with the heat treatment, a sample was taken at 'zero' time, and also at $15 \mathrm{~min}$ intervals for $\mathrm{l} \mathrm{h}$, and plated for single colonies. Cultures were incubated at $28^{\circ} \mathrm{C}$ in a shaking water bath. All experiments were done three times.

Method for assessing the rate of lysis by Zymolyase. Cells in exponential phase and stationary phase were centrifuged at 6000 r.p.m. ( $3000 \mathrm{~g}$ ) for $2 \mathrm{~min}$, and resuspended to $\mathrm{OD}_{600} 0.7$ in $10 \mathrm{mM}-\mathrm{Tris} / \mathrm{HCl}, \mathrm{pH} 7.5,1 \mathrm{mM}-$ DTT, 1 U Zymolyase 5000 (Miles) $\mathrm{ml}^{-1}$ (this is the buffer normally used for protoplast formation by Zymolyase, but it lacks the osmoticum sorbitol). Initial $\mathrm{OD}_{600}$ readings were taken, and further readings were taken at $15 \mathrm{~min}$ intervals for $1 \mathrm{~h}$. Results are expressed as a proportion of the initial $\mathrm{OD}_{600}$ and all experiments were done three times.

Measurement of cell size and cell number. Cells were grown in $2.5 \mathrm{ml}$ YEPD media in a $25 \mathrm{ml}$ conical flask as previously described. Cell numbers and cell volume measurements were made with a Coulter counter model ZB1, $\mathrm{C} 1000$ analyser and slave recorder. Latex beads $(4.63 \mu \mathrm{m}$ diameter $)$ were used as size standards. In our hands this method always gives slightly smaller cell volumes than measurements made from photographs (Sudbery et al., 1980). For the determination of cell volume distribution, the C1000 analyser was set to stop analysis when 1000 cells had been scored with the modal volume.

Glycogen assays. Glycogen levels in terms of yeast biomass were determined by the enzymic method of Quain (1981) and are the total amount of glycogen (the sum of acid-soluble and alkali-soluble fractions). The total amount of glycogen was calculated from the mean of duplicate or triplicate samples and is expressed in terms of glucose equivalents as a percentage of the total dry weight. For duplicate dry weight determinations, yeast cells were harvested by centrifugation, washed twice and dried at $105^{\circ} \mathrm{C}$ for $72 \mathrm{~h}$ to constant dry weight values.

\section{RESULTS}

\section{Definition of exponential and stationary phase cultures}

Stationary phase cultures were prepared by inoculating exponential cultures into fresh YEPD medium at a density of $2 \times 10^{6}$ cells ml-1 and then incubating with vigorous aeration for $48 \mathrm{~h}$. After this time cell numbers of both the mutant and the wild-type had stopped increasing (Fig. 1 ), and the percentage of budded cells, the percentage of phase bright cells and cell size had all reached constant values (data not shown). Exponential phase cultures were inoculated as described above but the cell number was not permitted to rise above $10^{7}$ cells $\mathrm{ml}^{-1}$ (measured routinely as $\mathrm{OD}_{600} 0 \cdot 6$ ). At this point, cell numbers were still increasing exponentially (Fig. 1).

\section{Construction and characterization of an isogenic strain}

In order to ensure that differences between wild-type and mutant strains were due solely to the whi2 allele, an isogenic strain was constructed. $\mathrm{X} 4003-5 \mathrm{~B}$ was chosen as a parent because it has a clear wild-type phenotype in stationary phase. In addition it transforms efficiently, which is a desirable property for molecular studies. X4003-5B was crossed to M11-30, a Met $^{-}$derivative of 


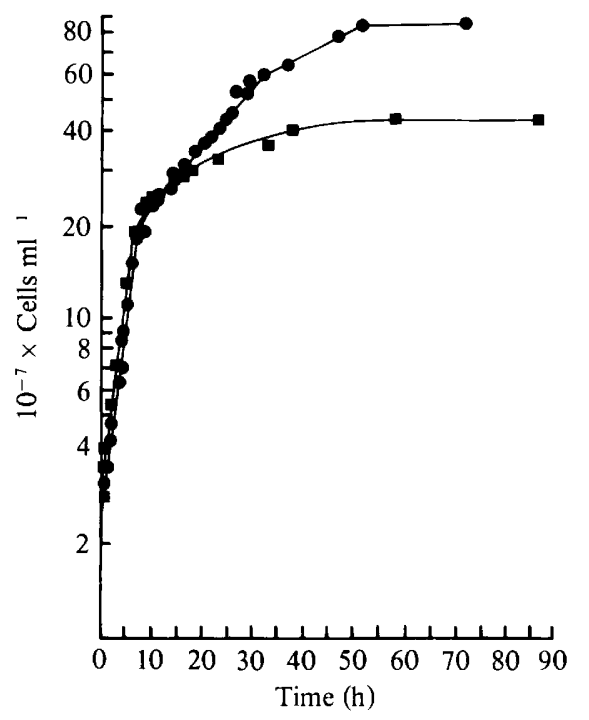

Fig. 1

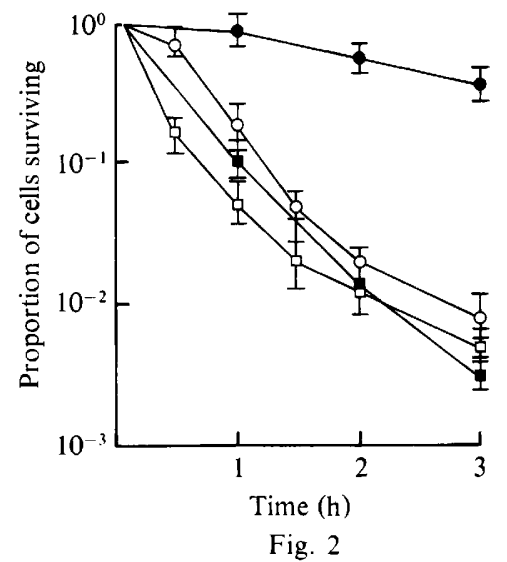

Fig. 2

Fig. 1. S. cerevisiae strains $\mathrm{X} 2180 \mathrm{IA}\left(\mathrm{WHI}^{+}\right)$and $\mathrm{M} 11$ (whi2) were grown to exponential phase in YEPD and inoculated into fresh YEPD at a cell density of $2 \times 10^{6}$ cells $\mathrm{ml}^{-1}$. Samples for analysis were taken when the cultures had reached a density of $3 \times 10^{7}$ cells $\mathrm{ml}^{-1}$., X2180 1A;, M11.

Fig. 2. Sensitivity to $52{ }^{\circ} \mathrm{C}$ heat shock of stationary phase and exponential phase cultures of X4003-5B and ISO34. Error bars represent SEM. $\square$, X4003-5B exponential phase; $\bigcirc$, X4003-5B stationary phase; $O$, ISO34 exponential phase; $\mathbf{\square}$, ISO34 stationary phase.

Table 1. Physiological characteristics of X4003-5B (WHI2+) and ISO34 (whi2) strains

\begin{tabular}{|c|c|c|c|c|c|c|}
\hline \multirow[b]{2}{*}{$\begin{array}{c}\text { Strain } \\
\text { genotype }\end{array}$} & \multirow[b]{2}{*}{$\begin{array}{l}\text { Growth* } \\
\text { phase }\end{array}$} & \multirow[b]{2}{*}{$\begin{array}{c}\text { Final cell } \\
\text { density }\end{array}$} & \multicolumn{2}{|c|}{ Cell volume $\left(\mu \mathrm{m}^{3}\right) \dagger$} & \multirow[b]{2}{*}{$\begin{array}{l}\text { Budded } \\
\text { cells }(\%) \dagger\end{array}$} & \multirow[b]{2}{*}{$\begin{array}{l}\text { Phase dark } \\
\text { cells }(\%)^{\dagger}\end{array}$} \\
\hline & & & Mode & $\overline{\text { Median }}$ & & \\
\hline$W H 2^{+}$ & Exponential & NA & 38 & 0) & $\begin{array}{c}74 \\
(512)\end{array}$ & $\begin{array}{c}94 \\
(526)\end{array}$ \\
\hline whi2 & Exponential & $\mathrm{NA}$ & 39 & 45 & $\begin{array}{c}77 \\
(535)\end{array}$ & $\begin{array}{c}96 \\
(560)\end{array}$ \\
\hline$W H I 2^{+}$ & Stationary & $1.23 \times 10^{8}$ & 36 & 0) 45 & $\begin{array}{c}8 \\
(542)\end{array}$ & $\begin{array}{c}4 \\
(569)\end{array}$ \\
\hline whi2 & Stationary & $3.91 \times 10^{8}$ & 20 & 0) 24 & $\begin{array}{c}74 \\
(510)\end{array}$ & $\begin{array}{c}94 \\
(544)\end{array}$ \\
\hline
\end{tabular}

* As defined in the text.

$\dagger$ Numbers in parentheses are numbers scored. NA, Not applicable.

M11 (Sudbery et al., 1980). The whi2 progeny were used for two further backcrosses to X4003-5B to produce ISO34, the genotype of which is $\alpha$ whi2 leu 2 his $4 \operatorname{trp} 5$, and which is $87.5 \%$ isogenic to X4003-5B.

Comparison of the properties of X4003-5B $\left(\mathrm{WHI}^{+}\right)$and ISO34 (whi2) show that the effect of the whi 2 allele is exactly as originally reported by Sudbery et al. (1980) when the whi2 allele was in a different genetic background. Measurements were made in a YEPD medium of cell density, cell size, percentage of cells budded and percentage of cells phase dark. The results (Table 1) show that exponentially growing cultures of both types are identical, but that in stationary phase whi 2 cells are smaller, phase dark, budded and have attained a higher cell density. 


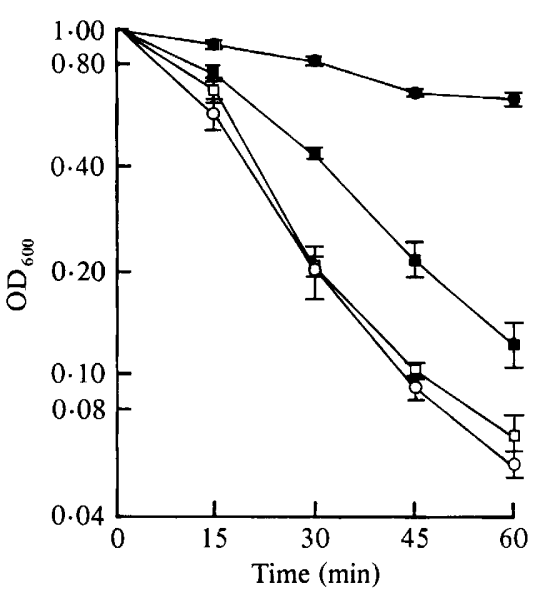

Fig. 3

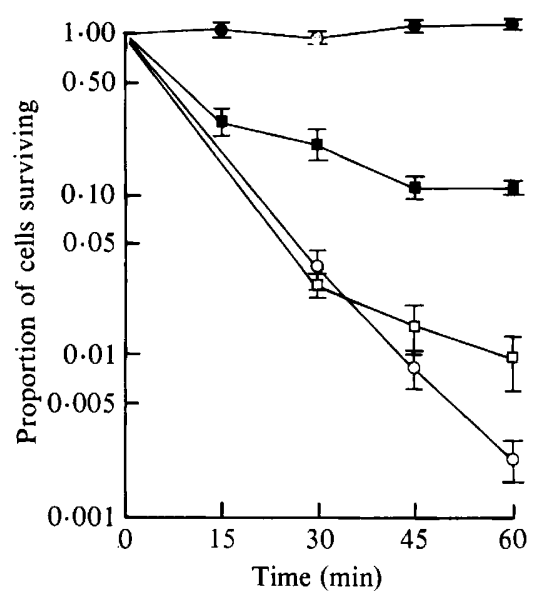

Fig. 4

Fig. 3. Sensitivity to Zymolyase $\left(1 \mathrm{U} \mathrm{ml}^{-1}\right)$ of stationary phase and exponential phase cultures of X4003-5B and ISO34. Error bars represent SEM. Symbols are as in Fig. 2.

Fig. 4. Sensitivity to nystatin $\left(100 \mathrm{U} \mathrm{ml}^{-1}\right)$ of stationary phase and exponential phase cultures of X4003-5B and ISO34. Errors bars represent SEM. Symbols are as in Fig. 2.

\section{The effect of elevated temperatures on $\mathrm{WHI}^{+}$and whi 2 cells}

Cells of X4003-5B and ISO34 were grown to both exponential and stationary phases, and the whole cultures were then heated to $52{ }^{\circ} \mathrm{C}$ (see Methods). At intervals, samples were withdrawn, diluted appropriately and plated on YEPD medium. The viable count was recorded. Combined data from triplicate experiments were plotted as a function of time (Fig. 2). In exponential phase the sensitivities of $\mathrm{X} 4003-5 \mathrm{~B}\left(\mathrm{WHI}^{+}\right)$and ISO34 (whi2) were similar. In stationary phase, however, whi 2 cells became more sensitive to the heat treatment while $\mathrm{WHI}^{+}$cells were less sensitive. The result was that whi 2 cells were 500 -fold less viable than the $W H I 2^{+}$cells after $4 \mathrm{~h}$ treatment.

\section{Sensitivity of $\mathrm{WHI}^{+}$and whi2 cultures to Zymolyase}

This was determined by incubating cells with $1 \mathrm{U}$ Zymolyase $\mathrm{ml}^{-1}$ in the absence of an osmoticum. Preliminary experiments had determined that at this concentration wild-type cells were unaffected in stationary phase but suffered substantial lysis in exponential phase. The decrease in $\mathrm{OD}_{600}$ (as cells lysed) plotted against time is shown in Fig. 3. In exponential phase $\mathrm{X} 4003-5 \mathrm{~B}$ and ISO34 showed similar, rapid rates of lysis. In stationary phase, however, the rate of lysis for the wild-type strain fell dramatically, whilst the whi2 cells showed only a slight increase in resistance.

\section{Sensitivity of $\mathrm{WHI}^{+}$and whi2 cultures to nystatin}

This was determined by incubating cells in different growth phases in the presence of $100 \mathrm{U}$ nystatin $\mathrm{ml}^{-1}$. The number of viable cells was determined at regular intervals (Fig. 4): whi2 cells were more sensitive to nystatin in both phases of growth but cells of X4003-5B, in stationary phase, were completely resistant. Stationary phase cells of ISO34, however, maintained a degree of sensitivity which resulted in only 1 in 10 cells surviving after a 60 min incubation.

\section{Glycogen accumulation}

As measured by the method of Quain (1981), both $\mathrm{WHI}^{+}$and whi2 cells have low levels of glycogen $(<1.1 \%$ of dry weight $)$ during exponential phase while in stationary phase $\mathrm{WHI}^{+}$had higher glycogen levels than whi2 (Table 2). Similar results for stationary phase cells (data not shown) were obtained with the modified method for glycogen determination of Gunja-Smith $e t$ al. (1977), as described by Lillie \& Pringle (1980). These results indicate that whi2 cells have a 
Table 2. Glycogen levels of $\mathrm{WHI}^{+}$and whi2 cells in exponential and stationary phase

$\begin{array}{llc}\begin{array}{c}\text { Strain } \\ \text { genotype }\end{array} & \text { Growth phase* } & \begin{array}{c}\text { Glycogen content } \\ (\% \text { dry wt }) \dagger\end{array} \\ \text { WHI }{ }^{+} & \text {Exponential } & 1 \cdot 03 \pm 0.03 \\ W_{H} 2^{+} & \text {Stationary } & 3 \cdot 56 \pm 0.32 \\ w h i 2 & \text { Exponential } & 0 \cdot 88 \pm 0 \\ w h i 2 & \text { Stationary } & 1.9 \pm 0.02 \\ & \text { * As defined in the text. } \\ & \dagger \text { Means } \pm \text { SEM. }\end{array}$

Table 3. Cell cycle distribution of cells as revealed by DAPI staining

\begin{tabular}{|c|c|c|c|c|c|c|}
\hline \multirow[b]{2}{*}{$\begin{array}{c}\text { Strain } \\
\text { genotype }\end{array}$} & \multirow[b]{2}{*}{ Growth phase* } & \multirow[b]{2}{*}{$\begin{array}{l}\text { Budded } \\
\text { cells }(\%)\end{array}$} & \multicolumn{3}{|c|}{ Fraction of budded cells } & \multirow{2}{*}{$\begin{array}{l}\text { Total number } \\
\text { of budded } \\
\text { cells counted }\end{array}$} \\
\hline & & & $\begin{array}{l}\text { Before nuclear } \\
\text { division } \dagger\end{array}$ & $\begin{array}{l}\text { In nuclear } \\
\text { division }\end{array}$ & $\begin{array}{c}\text { After nuclear } \\
\text { division } \S\end{array}$ & \\
\hline $\mathrm{WH} \mathrm{I}^{+}$ & Exponential & $71 \cdot 2$ & $0 \cdot 32$ & 0.41 & $0 \cdot 27$ & 213 \\
\hline $\mathrm{WHI}^{+}$ & Stationary & $2 \cdot 4$ & $0 \cdot 31$ & $0 \cdot 02$ & $0 \cdot 67$ & 100 \\
\hline whi2 & Exponential & $74 \cdot 5$ & 0.49 & $0 \cdot 22$ & $0 \cdot 29$ & 172 \\
\hline \multirow[t]{2}{*}{ whi2 } & Stationary & $17 \cdot 2$ & $0 \cdot 34$ & $0 \cdot 17$ & 0.49 & 207 \\
\hline & $\begin{array}{l}* \text { As defined } \\
\dagger \text { Cells with } \\
\ddagger \text { Cells with } \\
\S \text { Binucleate }\end{array}$ & $\begin{array}{l}\text { e text. } \\
\text { le nucl } \\
\text { ding } n \\
\text { with a }\end{array}$ & $\begin{array}{l}\text { the mother } \\
\text { in the neck b } \\
\text { in both the }\end{array}$ & $\begin{array}{l}\text { en mothe } \\
\text { eer and } d\end{array}$ & $\begin{array}{l}\text { daughter } \\
\text { ter cells. }\end{array}$ & \\
\hline
\end{tabular}

reduced ability to accumulate glycogen upon cessation of growth in stationary phase - a property of resting state cells (Lillie \& Pringle, 1980).

whi 2 cells show no single point of arrest in the cell cycle

Studies with Schizosaccharomyces pombe have shown that this yeast exerts a cell size control both in the G1 and G2 phase of the cell cycle (Nurse \& Bissett, 1981; Nurse \& Fantes, 1981). In addition, recent studies with a small mutant (whil) of $S$. cerevisiae suggests that wild-type cells may also have a cryptic second cell size control later in the cell cycle other than at 'Start' ( $F$. Wynne, personal communication). One explanation for the relatively high percentage of budded whi 2 cells in stationary phase is that as cells approach stationary phase at a reduced growth rate and at an abnormally reduced cell size, they produce a bud, but are of insufficient size to transverse a second cell size control and so are unable to complete budding. If this were the case, then the budded cells in a stationary phase population of whi2 may consist of cells that arrest at one specific event of the cell cycle, e.g. nuclear division.

To investigate this possibility, stationary phase cultures of whi2 and $\mathrm{WHI}^{+}$were stained with the fluorescent nuclear stain 4',6-diamidino-2-phenylindole (DAPI) (Williamson \& Fennell, 1975). This treatment gives a visual indication of the nucleus within the budded cell and hence an approximation of the position of the cell in the cell cycle. Budded cells were divided into the following three categories, according to the position of the nucleus within the cell: (a) those arrested prior to nuclear division; (b) those arrested in nuclear division and (c) those arrested after nuclear division.

As expected in stationary phase, whi2 cultures had a higher proportion of budded cells than $\mathrm{WHI}^{+}$cultures (Table 3 ). In addition, there was a difference in the proportion of each type of budded cell between strains in stationary phase. Wild-type cells consisted almost entirely of two types: those that had arrested before nuclear division and those that had arrested before cell division. The latter category was the most common. Since cells were sonicated before DAPI staining, these cells are probably unable to complete cytokinesis. Stationary phase whi 2 budded cells show significant numbers in each division of the cell cycle. There is therefore no single point at which cells arrest but a minimum of three, and the data would be consistent with there being no preferential point or points of arrest. 
DISCUSSION

During exponential phase growth on rich medium in batch culture, wild-type and whi 2 cells are indistinguishable. However, at the end of the exponential phase when the growth rate becomes reduced and glucose is depleted, a number of changes are observed in wild-type cells which do not occur in whi 2 cells. During this period of reduced growth wild-type cells accumulate glycogen and the proportion of phase bright cells increases; eventually these $W H I 2^{+}$ cells cease proliferating as unbudded phase bright cells in the G1 period of the cell cycle.

whi 2 cells show a greatly increased proportion of budded cells which have arrested at all stages of the cell cycle. This suggests that whi2 cells become committed to the initiation of the cell cycle without the necessary requirements to complete it when nutrients finally become depleted. The continued cell division in the absence of growth leads to the reduction in cell size and the increased final cell density. whi 2 cells are now more sensitive to heat treatment, nystatin treatment and Zymolyase digestion of the cell wall compared to stationary phase $\mathrm{WHI}^{+}$cells, suggesting that in stationary phase the mutant maintains properties of exponential phase cells and is unable to assume the characteristics of quiescent cells. This is further supported by the observation that whi2 stationary phase cells have a reduced ability to accumulate glycogen as compared to wild-type cells.

The low proportion of phase bright cells upon cessation of growth by the mutant in stationary phase may be due to the reduced ability to accumulate glycogen and possibly to a change in cell wall composition. This hypothesis is supported by several studies relating glycogen content and resistance to cell wall degrading enzymes to the phase bright appearance of cells. Kuenzi (1970; cited by Fiechter 1975), observed that wild-type cultures grown at slow mass doubling times in a glucose-limited chemostat consisted of both phase bright cells which stained glycogen positive with iodine, and phase dark cells which stained glycogen negative. Bugeja et al. (1982), who also observed phase bright and dark cells at slow growth rates in a glucose-limited chemostat, found that phase bright cells appear to be more resistant to cell wall degrading enzymes. These results suggest that phase bright cells have an altered cell wall composition with respect to phase dark cells.

Changes in the sensitivity to nystatin again suggest changes in either the cell wall, the cell membrane, or both. The possibility that the presence of membrane sterols (Hamilton-Miller, 1974; Parks, 1978) is a prerequisite for sensitivity to polyene antibiotics has been suggested by Lampen (1962) who proposed that nystatin combines with ergosterol, a major component of the cell membrane, causing damage to the integrity and permeability of the plasma membrane (see Parks, 1978, for a review). However, changes in the degree of unsaturation and length of fatty acids in the cell membrane may alter the effects of some polyene antibiotics (Koh et al., 1977). Thus the extent of sensitivity to nystatin may reflect the composition of the plasma membrane under specific conditions and may explain the difference in sensitivity between whi2 and the wild-type.

The cell wall may also bind nystatin, thereby mitigating its effect on the cell membrane (Lampen, 1962). Thus changes in cell wall composition may contribute to the decreased sensitivity of wild-type stationary phase cells. The continued sensitivity of whi2 stationary phase cells may thus result in a failure to show the normal cell wall reorganization.

The results reported in this paper confirm previous observations that in response to nutrient deprivation the properties of yeast cells undergo a series of changes. These changes are sometimes said to constitute a separate state termed G0 (Pinon, 1978, 1979; Pinon \& Platt, 1979; Pringle \& Hartwell, 1981). Cells bearing the whi2 mutation do not show these changes and can therefore be said to be unable to enter G0. This failure may be due to an inability to monitor the nutritional status of the external environment or may be due to the loss of a function required to enter $\mathrm{G} 0$. The results presented here do not distinguish between these possibilities.

\section{REFERENCES}

Bugeja, V. C., Piggot, J. R. \& Carter, B. L. A. (1982). Differentiation of Saccharomyces cerevisiae at slow growth rates in glucose-limited chemostat culture. Journal of General Microbiology 128, 27072714.

DeUtch, C. E. \& PARRY, J. M. (1974). Sphaeroplast 
formation in yeast during the transition from exponential phase to stationary phase. Journal of General Microbiology 80, 259-268.

FieChTER, A. (1975). Continuous cultivation of yeasts. Methods in Cell Biology 11, 97-130.

Gunja-Smith, Z., Patil, N. B. \& SMith, E. E. (1977). Two pools of glycogen in Saccharomyces cerevisiae. Journal of Bacteriology 13, 818-825.

Hamilton-Miller, J. M. T. (1974). Fungal steroids and the mode of action of the polyene antibiotics. Advances in Applied Microbiology 17, 109-134.

HARTWELL, L. H. (1974). Saccharomyces cerevisiae cell cycle. Bacteriological Reviews 38, 164-198.

Koh, T. Y., MarriotT, M. S., TAylor, J. \& Gale, E. F. (1977). Growth characteristics and polyene sensitivity of a fatty acid auxotroph in Candida albicans. Journal of General Microbiology 102, 105110.

Lampen, J. O., ARnow, P. M., BorowsKa, Z. \& LASKIN, A. I. (1962). Location and role of sterol at nystatin-binding sites. Journal of Bacteriology $\mathbf{8 4}$, 1152-1160.

Lillie, S. H. \& Pringle, J. R. (1980). Reserve carbohydrate metabolism in Saccharomyces cerevisiae: responses to nutrient limitation. Journal of Bacteriology 143, 1384-1394.

NuRSE, P. \& BissetT, Y. (1981). Gene required in G1 for commitment to cell cycle and in G2 for control of mitosis in the fission yeast. Nature, London 292, 558560.

NURSE, P. \& Fantes, P. A. (1981). Cell cycle controls in fission yeast: a genetic analysis. In The Cell Cycle, p. 85. Edited by P. L. C. John. Cambridge: Cambridge University Press.

PARKs, L. W. (1978). Metabolism of sterols in yeast. Critical Reviews in Microbiology 6, 301-341.

Parry, J. M., Davies, P. J. \& Evans, W. E. (1976). The effects of "cell age" upon the lethal effects of physical and chemical mutagens in yeast. Molecular and General Genetics 146, 27-35.

PINON, R. (1978). Folded chromosomes in non-cycling yeast cells. Evidence for a characteristic G0 form. Chromosoma 67, 263.
Pinon, R. (1979). A probe into nuclear events during the cell cycle of Saccharomyces cerevisiae: studies of folded chromosomes in $\mathrm{cdc}$ mutants which arrest in G1. Chromosoma 70, 337-352.

Pinon, R. \& Pratt, D. (1979). Folded chromosomes of mating-factor arrested yeast cells: comparison with G0 arrest. Chromosoma 73, 117-129

Pringle, J. R. \& Hartwell, L. H. (1982). The Saccharomyces cerevisiae cell. In The Molecular Biology of the Yeast Saccharomyces. Life Cycle and Inheritance, pp. 97-142. Edited by J. N. Strathern, E. W. Jones \& J. R. Broach. New York: Cold Spring Harbor Laboratory.

QUAIN, D. E. (1981). The determination of glycogen in yeasts. Journal of the Institute of Brewing 87, 289-291.

Schenberg-Frascino, A. \& Moustacchi, E. (1972). Lethal and mutagenic effects of elevated temperature on haploid yeast. 1. Variations in sensitivity during the cell cycle. Molecular and General Genetics 115, 243-257.

Sherman, F., Fink, G. R. \& LaWrence, C. W. (1974). Methods in Yeast Genetics. New York: Cold Spring Harbor Laboratory.

SNow, R. (1966). An enrichment method for auxotrophic yeast mutants using "Nystatin". Nature, London 211, 206-207.

Sudbery, P. E., Goodey, A. R. \& CARTer, B. L. A. (1980). Genes which control cell proliferation in the yeast Saccharomyces cerevisiae. Nature, London $\mathbf{2 8 8}$, 401-404.

Thouvenot, D. E. \& Bourgeors, C. M. (1971). Optimisation de la selection de mutants de Saccharomyces cerevisiae par la nystatine. Annales de l'Institut Pasteur 120, 617-625.

Walton, E. F., Carter, B. L. A. \& Pringle, J. R. (1979). An enrichment method for temperaturesensitive and auxotrophic mutants of yeast. Molecular and General Genetics 171, 111-114.

Williamson, D. H. \& FenNell, D. J. (1975). The use of fluorescent DNA binding agent for detecting and separating yeast mitochondrial DNA. Methods in Cell Biology 12, 335-351. 